JURNAL PENDIDIKAN, p-ISSN 2715-095X, e-ISSN 2686-5041

Volume 30, No.2, Juli 2021 (235-244)

Online: http://journal.univetbantara.ac.id/index.php/jp

\title{
Analisis Kebijakan Zonasi: Terampasnya Hak Sekolah dan Hak Siswa dalam Pendidikan
}

\author{
Iske Mareta, Nur Wahdaniah Ijatul Islamiah, Dina Rosa, dan Indah Ayuningtyas \\ Universitas Ahmad Dahlan, Daerah Istimewa Yogyakarta, e-mail: \\ iske1900031238@webmail.uad.ac.id, indah1900031299@webmail.uad.ac.id, \\ dina1900031260@,webmail.uad.ac.id,nur1900031243@webmail.uad.ac.id
}

Received: Mey 17, 2021

Accepted: Juni 1, 2021

Online Published: Juni 26, 2021

\begin{abstract}
Abstrak: Ketimpangan dan pengkastaan dalam ranah pendidikan membuat pemerintah bergerak untuk membuat kebijakan baru demi mengatasi permasalahan tersebut. Kebijakan zonasi disebut-sebut sebagai salah satu kebijakan yang mampu untuk menangani segala pengkastaan dan ketimpangan pendidikan dalam melabeli suatu sekolah favorit dan non favorit. Dengan menggunakan metode Literatur Review menggunakan kepustakaan dalam mengumpulkan referensi dari berbagai buku maupun jurnal terkait. Penelitian ini mencoba untuk menjawab hak sekolah dan hak siswa yang seperti apa yang terampas akibat kebijakan zonasi. Hasil yang kami temui mengemukakan bahwasannya kebijakan zonasi telah mampu menghapus ketimpangan pendidikan dalam pelabelan sekolah favorit namun tidak dengan ketimpangan kualiatas sebuah sekolah. Sehingga perlu adanya pembenahan lebih lanjut pada aspek kualitas maupun prasarana dibanding hanya fokus pada aspek input siswa.
\end{abstract}

Kata-kata Kunci: Pendidikan, Kebijakan, Zonasi

\section{Zoning Policy Analysis: The Loss of School Rights and Student Rights in Education}

\author{
Iske Mareta, Nur Wahdaniah Ijatul Islamiah, Dina Rosa, and Indah Ayuningtyas \\ Ahmad Dahlan University, Special Region of Yogyakarta, e-mail: \\ Iske1900031238@webmail.uad.ac.id, indah1900031299@webmail.uad.ac.id, \\ dina1900031260@webmail.uad.ac.id,nur1900031243@webmail.uad.ac.id
}

\begin{abstract}
Inequality and education have led the government to move to create new policies to address the problem. Zoning policy is referred to as one of the policies that can handle all education inequality and inequality in labeling a favorite and non-favorite school. By using the literature review method use literature in collecting references from various books and related journals. The study tries to address the rights of schools and what kind of rights students are affected by zoning policies. The results we found suggest that zoning policies have been able to erase educational inequality in the labeling of a favorite school but not with the inequality of a school's quality. So there needs to be further improvement in the quality and infrastructure aspects rather than just focusing on the input aspects of students.
\end{abstract}

Keywords: Education, Policy, Zoning 


\section{Pendahuluan}

Pesatnya perkembangan zaman membuat berbagai perubahan di setiap sendi kehidupan tidak terkecuali dalam ranah pendidikan. Pendidikan menjadi salah satu aspek yang terus menerus berubah seiring perkembangan zaman (Suwarto,2017). Aspek dalam pendidikan yang paling sering diubah dan dikembangkan adalah aspek kebijakan. Dimana kebijakan sendiri memegang peranan penting dalam lingkup pendidikan. Kebijakan dapat diartikan sebagai aturan atau ketentuan tertulis dari keputusan sebuah lembaga atau organisasi yang sifatnya mengikat dan mengatur tindakan seseorang guna mencapai tujuan dan menciptakan tata nilai baru dalam lembaga maupun organisasi tersebut (Arwildayanto, Arifin Suking, \& Warni Sumar Tune, 2018: 6). Dalam hal kebijakan pendidikan pemerintah telah banyak mengubah dan membenahi segala macam kebijakan yang ada di lingkup pendidikan Indonesia. Di tahun 2017 sendiri merupakan salah satu tahun yang menjadi bukti dimulainya kebijakan baru pendidikan. Kebijakan yang diharapkan mampu untuk mengatasi ketimpangan dan pengkastaan pendidikan, yaitu kebijakan sistem zonasi. Zonasi berasal dari kata zona yang artinya kawasan atau area yang banyak fungsinya. Sedangkan sistem zonasi sendiri adalah salah satu bentuk yang dibuat oleh kementerian pendidikan dan kebudayaan atau Kemendikbud dengan tujuan yaitu menciptakan adanya pemerataan terhadap akses pada layanan pendidikan, dan pemerataan kuantitas dan kualitas pendidikan nasional (Siti, 2018). Berdasar pengertian zonasi tersebut mungkin kita akan teringat mengenai salah satu sistem yang tidak asing ditelinga kita yaitu sistem rayonisasi. Jadi, pada dasarnya sistem zonasi ini merupakan pengembangan lebih lanjut dari sistem rayonisasi. Pembeda antar rayonisasi dan zonasi terletak pada pembagian wilayahnya. Rayonisasi sendiri melakukan pembagian wilayah berdasarkan kesepakatan sedangkan sistem zonasi dalam pembagian wilayah lebih menekankan kepada fungsi dan tujuan pengelolanya. Dalam lingkup pendidikan, yang menjadi fungsi dan tujuan pengelolanya adalah pemerataan mutu pendidikan disetiap satuan-satuan pendidikan yang ada di Indonesia (Perdana, 2019).

Penerapan kebijakan zonasi pada tahun 2019 mulai diberlakukan untuk tingkat SMP dan SMA di Indonesia secara serentak. Tercatat pada tanggal 5 Februari 2019, sudah ada 18 provinsi dari 34 provinsi yang mulai menyerahkan penetapan zonasi di sekolah menengah atas (Pengelola web kemdikbud, 2019a). Dalam penerapan kebijakan zonasi di dua tingkat pendidikan tersebut menimbulkan banyak pro dan kontra, bahkan jumlah masyarakat yang kontra dengan kebijakan zonasi ini terhitung lebih banyak jumlahnya. Sebagai contoh, implementasi sistem zonasi di berbagai SMA di kota Bima memunculkan tiga permasalahan baru. Pertama, peserta di kota Bima tidak bisa lagi berkompetisi kecuali dalam sistem zonasi artinya kompetisi jarak rumah ke sekolah. Kedua, rata-rata prestasi peserta didik menurun karena siswa yang berprestasi disebar diseluruh zona. Hal ini sebagai salah satu usaha kebijakan zonasi agar dapat mengatasi ketimpangan pendidikan. Jadi mau tidak mau, sekolah harus menerima murid yang beragam bahkan menerima murid dengan nilai rendah jika murid tersebut masuk dalam kawasan zonasi. Ketiga, adanya sistem zonasi membuat disiplin belajar menurun dan meningkatnya pelanggaran tata tertib (Hendrawansyah \& Zamroni, 2020). Adapun kalangan masyarakat kontra yang berpendapat bahwa kebijakan ini merugikan mereka (Suwarto, 2009). Berkurangnya kelas-kelas unggulan karena mereka merasa kesulitan memasukan anak mereka ke lembaga favorit yang jaraknya jauh sehingga mereka berargumen bahwa hal ini dapat membatasi anaknya untuk berkembang (Thoha \& Ghazali, 2020). Dari argumen kontra di atas, kita dapat mengetahui upaya pemerintah dalam menghapus label sekolah favorit dan non favorit 
belum dapat diterima dan dipahami sepenuhnya oleh masyarakat. Terbukti beberapa dari mereka masih bersih kukuh memasukan anak mereka ke lembaga favorit sekalipun label tersebut sudah dihapus oleh pemerintah. Demikian ini artinya, stigma sekolah favorit masih melekat di masyarakat. Hal ini juga tak bisa disalahkan, karena mengingat penghapusan label tanpa peningkatan kualitas, sarana prasarana dan sebagainya di semua pendidikan menunjukan bahwa penerapan kebijakan ini belum maksimal. Adanya argumen kontra yang demikian keluar tanpa dasar jelas. Mengingat pemerintah membuat jalur zonasi lebih utama dibanding jalur lainnya. Jalur zonasi sendiri menempati posisi pertama dan persentase tertinggi dalam Penerimaan Peserta Didik Baru (PPDB) dibanding jalur lainnya. Pada tahun 2020 kemarin, Mentri Pendidikan baru Indonesia yaitu Nadiem Makarim membahas kembali kajian mengenai kebijakan zonasi ini, Nadiem menyatakan bahwa ia mendukung penuh adanya jalur zonasi. Namun, di masa jabatannya Nadiem merombak beberapa bagian dari kebijakan karena ia menyadari tidak semua wilayah siap dengan kebijakan tersebut maka Kemdikbud pun mengeluarkan kebijakan kompromi dari zonasi dengan menambah kuota jalur prestasi menjadi 30 persen (sebelumnya 15 persen), dan mengurangi kuota jalur zonasi menjadi minimal 70 persen (sebelumnya minimal 80 persen) (Pengelola web kemdikbud, 2019b). Meskipun sistem zonasi mendapat persentase terbanyak dalam jalur PPDB tidak berarti sistem zonasi ini tidak memiliki ketentuan dalam pelaksanaannya.

Setiap adanya kebijakan pasti ada ketentuan yang harus di terapkan begitu juga dengan kebijakan sistem zonasi ini. Adapun urutan prioritas peserta didik yang di terima berdasarkan ketentuan kelompok belajar adalah, 1) jarak rumah dan sekolah sesuai ketentuan zonasi, 2) Umur atau usia, 3) Adanya nilai nilai hasil ujian sekolah dan surat hasil ujian nasional, 4)sesuai dengan ketetapan daerah masing-masing presentasi di bidang akademik dan non-akademik harus di akui (Siti, 2018). Seperti yang dikatakan sebelumnya bahwa kebijakan zonasi dibuat dengan tujuan untuk mengatasi ketimpangan dan peningkatan mutu suatu sekolah. Suatu kebijakan tidak akan dijalankan jika tidak memiliki manfaat bagi masyarakat. Maka dalam sebuah penelitian mengemukakan beberapa manfaat dari adanya sistem zonasi ini, diantaranya 1) meningkatkan kuantitas dan kualitas, 2) pemerataan, 3)Memudahkan dalam pengelolaan (Siti, 2018). Namun perlu diakui bahwa selama berjalannya kebijakan zonasi tidak begitu banyak membuahkan hasil dan mencapai target tujuan awal yaitu memperbaiki kualiatas sekolah dan menghilangkan persepsi sekolah favorit dan non favorit. Kebijakan zonasi ini justru menimbulkan banyak masalah baru. Tidak jarang banyak hak-hak masyarakat yang terampas akibat kebijakan ini. Betul, memang setiap kebijakan memiliki kekurangan dan kelebihan masing-masing, tetapi tidak dibenarkan untuk berkalut dalam kebijakan ini tanpa dibenahi kembali. Maka dari itu dalam penelitian ini berusaha untuk mencari tahu lebih dalam mengenai hak-hak seperti apa yang terampas akibat jalannya kebijakan zonasi ini. Dengan menjawab pertanyaan tersebut diharapkan dapat memenuhi tujuan penelitian ini yaitu mengetahui perihal hak sekolah dan hak siswa dalam pendidikan yang terampas akibat kebijakan zonasi.

\section{Metode Penelitian}

Penelitian ini merupakan penelitian dengan pendekatan Literature Review. Literature Review merupakan penelitian yang mengkaji atau meninjau secara kritis pengetahuan, gagasan, atau temuan yang terdapat didalam tubuh literatur berorientasi akademik (academic-oriented literature), serta merumuskan kontribusi teoritis dan metodologinya untuk topik tertentu.Sumber data yang diambil dalam penelitian ini adalah literasi baik dari buku maupun jurnal yang berkaitan dengan Relasi antara Hak Sekolah dan 
Hak Siswa dalam Pendidikan. Pengambilan data melalui penelusuran referensi yang terkait, baik secara manual atau digital. Analisis data dilakukan dengan menggunakan metode isi dan dilakukan proses pemilihan, pembandingan, penggabungan, pemilihan berbagai makna, hingga ditemukan makna yang relevan.

\section{Hasil Penelitian}

Berdasarkan penelitian yang dilakukan dengan menggunakan metode kepustakaan dapat dikemukakan ada beberapa hak yang terampas dari pemberlakuan kebijakan zonasi di ranah pendidikan. Hak-hak yang terampas bukan hanya dari kalangan siswa sebagai pelaku dalam jalannya kebijakan namun juga bagi sekolah selaku wadah pemberlakuan kebijakan tersebut. Hasil yang diperoleh bahwasannya dari sudut sekolah ada beberapa hak yang terampas diantaranya berkurangnya hak untuk kualitas sekolah. Demikian terjadi karena kebijakan ini menurunkan kualitas sekolah dengan cara minimnya siswa yang memilih sekolah dan persentase sekolah yang tidak seimbang. Hal ini tidak terlepas dari kurangnya perhatian pemerintah tentang pemerataan penduduk dan lembaga pendidikan sehingga kebijakan zonasi yang diharap mampu membereskan problema di ranah pendidikan justru menimbulkan persoalan baru yaitu tidak meratanya kehadiran lembaga pendidikan dan jumlah peserta didik.

Sejalan dengan hak yang terampas di sekolah, para siswa yang terlibat dalam kebijakan tersebut ikut merasakan terampasnya hak-hak karena pemberlakuan zonasi. Diantaranya yaitu tidak adanya hak untuk berkompetisi. Hak siswa untuk berkompetisi dirasa berkurang akibat dari pemberlakuan kebijakan zonasi. Kebiasaan yang umum terjadi sebelum kebijakan ini diterapkan adalah para siswa yang berkompetisi dalam perolehan nilai tertinggi demi bisa masuk ke sekolah favoritnya. Namun, berlangsungnya kebijakan ini membuat para siswa kehilangan motivasi dan harapan untuk masuk ke sekolah favorit dikarenakan persentase penerimaan zonasi lebih tinggi dibanding penerimaan pada jalur prestasi. Beruntung pada tahun 2020 pemerintah telah menambah kuota jalur prestasi sehingga anak-anak yang berjarak jauh memiliki kesempatan. Fakta ini tentu menyadarkan bahwa sejatinya pemerintah hanya mampu menghapus label sekolah favorit non favorit tapi tidak dengan stigma masyarakat tentang sekolah tersebut.

\section{Pembahasan}

Dalam kebijakan zonasi pemerintah berusaha untuk menghilangkan pandangan masyarakat mengenai adanya sekolah favorit dan non favorit. Sehingga semua sekolah yang ada di Indonesia bervalue sama dan siswa berhak mendapatkan pendidikan yang baik tanpa adanya pembeda status antar sekolah tersebut. Hal ini merupakan salah satu pengimplementasian nilai sila kelima yaitu "Keadilan sosial bagi seluruh rakyat Indonesia" yang mana pendidikan menjadi bentuk keadilan yang harus senantiasa di tegakan demi terciptanya generasi yang terdidik. Sekolah sebagai wadah kebijakan ini mendapat beberapa keuntungan sampai kerugian. Setiap putusan kebijakan akan selalu memperoleh hasil yang pro dan kontra begitu juga dengan adanya kebijakan zonasi ini. Hasil yang dituturkan oleh (Pradewi \& Rukiyati, 2019) dalam penelitiannya mengenai kebijakan zonasi setidaknya memperoleh 7 prespektif, dua diantaranya mengatakan kebijakan zonasi dianggap sebagai cara untuk memeratakan kualitas sekolah namun disisi lain dianggap sebagai salah satu yang menurunkan kualitas sekolah.

Zonasi Memeratakan Kualitas Sekolah: Hasil yang ditemukan dalam sebuah penelitian mengungkap kan bahwa zonasi dapat memeratakan kualitas sekolah hal ini karena pemerataan yang dilakukan pihak sekolah melalui dua hal yaitu : sekolah mempunyai kesempatan untuk mendapat input siswa yang unggul dan sekolah menerima 
siswa dengan bervariasi. Hal ini tentu dapat mengubah label sekolah favorit yang selama ini menjadi alasan adanya pengkastaan dalam dunia pendidikan (Pradewi \& Rukiyati, 2019). Singkatnya, terisinya sekolah dengan siswa yang beragam dapat mengubah pandangan masyarakat terhadap sekolah tersebut. Dimana sebelum adanya zonasi masyarakat cenderung melabeli atau membuat patokan untuk mengatakan sebuah sekolah favorit jika dipenuhi dengan siswa yang unggul saja dan sekolah lain sebagai sekolah non favorit ketika sekolah tersebut hanya terisi dengan anak-anak yang menurutnya jauh dari kata unggul. Dengan demikian dapat dikatakan bahwa zonasi bukan hanya untuk pemerataan kualitas saja tapi juga mengubah pandangan masyarakat soal pendidikan sebagaimana yang dikutip dari (Kemendikbud, 2018) : "Ini persoalan persepsi, dan soal mental. Karena itu, sistem zonasi ini juga merupakan bagian dari upaya kita melakukan revolusi mental masyarakat, terutama persepsinya tentang pendidikan," Selain itu dikatakan bahwa kebijakan zonasi juga dapat meningkatkan kualitas sekolah dikota-kota karena kebijakan ini mengatur pilihan tiap siswa secara langsung dimana hal ini dapat meningkatkan pilihan kepada sekolah tersebut dan meningkatkan kualitasnya karena banyak dipilih oleh masyarakat yang memiliki jarak rumah yang dekat dengan sekolah tersebut.

Menurunkan Kualitas Sekolah: Berbeda dengan hasil sebelumnya, dalam hasil penelitian yang lain justru menyebutkan bahwa kebijakan zonasi dapat menurunkan kualitas sekolah. Prespektif ini di dasari oleh argumen guru yang berpendapat bahwa dengan sistem zonasi artinya sekolah tidak dapat melakukan penyaringan siswa yang berprestasi karena sistem ini lebih mengutamakan wilayah tempat tinggal dibanding prestasi siswa. Selain itu, sistem zonasi dianggap melemahkan motivasi sekolah untuk berlomba-lomba menjadi sekolah yang unggul dengan label favorit karena dalam kebijakan zonasi setiap sekolah dinilai sama. Bahkan lewat kebijakan zonasi tak sedikit sekolah yang terancam gulung tikar karena tak ada peserta didik yang menjadikan sekolahnya pilihan. Hal ini terjadi karena kebijakan zonasi tidak diimbangi dengan pemerataan penduduk. Dimana dalam suatu wilayah persentase penduduk dan persentase sekolah yang ada tidak sama. Situasi ini menjadikan beberapa sekolah yang berada di lingkungan padat penduduk justru menerima siswa lebih banyak dari kuota yang tersedia sedangkan sekolah yang berada di wilayah minim penduduk mendapat siswa dibawah kuota yang disediakan.

Pada tahun 2019 di wilayah Bekasi, jalur zonasi sendiri menempati posisi pertama sebagai jalur Penerimaan Peserta Didik Baru (PPDB) yang paling diminati. Tercatat ada 28.470 calon siswa yang mendaftar di jalur zonasi murni padahal kuota yang tersedia hanya 10.737 kursi. Sedangkan untuk jalur afirmasi sendiri mendapati peminat sebanyak 1.519 calon siswa dengan kuota yang tersedia hanya sebanyak 1.425 kursi (Yusnilaningsih, 2019). Situasi ini tentu menjadi permasalahan baru dalam ranah pendidikan Indonesia. Kebijakan yang seharusnya dapat memajukan lembaga pendidikan dan kualiatas pendidikan itu sendiri justru menjadi awal mula permasalahan baru. Maka dari itu banyak protes yang dilayangkan pada kebijakan zonasi untuk di benahi ulang. Secara empiris sistem zonasi sebenernya tidak berkolerasi terhadap kualitas pendidikan. Hal ini karena pemerintah tidak banyak mengatur lebih jauh dan komprehensif bagaimana memperbaiki kualitas pendidikan. Zonasi hanya berputar-putar dengan akses yang didapat warganegara dengan pertimbangan jarak. Padahal yang seharusnya menjadi fokus utama untuk dikelola adalah kualitas sistem pembelajaran dan pendidikan bukan pada zonasi lokasi sekolahnya (Mahpudin, 2020).

Sejalan dengan pernyataan Mahpudin, (Abbas, 2019: 72) menyatakan bahwa : Dalam aspek kualitas pendidikan merujuk kepada kualitas proses dan produk. Suatu 
pendidikan disebut Bermutu dari segi proses (yang juga sangat dipengaruhi Kualitas masukannya) jika proses belajar-mengajar berlangsung secara efektif dan peserta didik mengalami proses pembelajaran yang bermakna, ditunjang oleh sumber daya (manusia, dana, sarana, dan prasarana) yang wajar. Dengan demikian, proses pendidikan yang berkualitas akan menghasilkan produk yang berkualitas pula sarana prasarana agaknya juga harus diperhatikan pemerintah ketika ingin memutuskan suatu kebijakan pendidikan. Sebab, salah satu penghambat dalam kebijakan zonasi adalah tidak meratanya sarana dan prasana dalam suatu sekolah. Padahal sarana dan prasaran sendiri merupakan penunjang dalam proses pendidikan. Bukan hanya penunjang dalam proses pembelajaran, sarana prasaran juga memiliki korelasi terhadap motivasi mengajar seorang guru.

Mengambil salah satu penelitian yang dilakukan di SMA Negeri 1 Pamijahan, para peneliti membuktikan bahwa terdapat hubungan yang sangat kuat dan positif antara sarana dan prasarana dengan motivasi mengajar guru (Jamil, 2020). Hal ini membuktikan bahwa memperhatikan sarana dan prasarana merupakan hal yang penting mengingat guru merupakan elemen utama dalam keberhasilan proses pembelajaran. Mengutip dari (Yuliani, 2019). Sarana menjadi salah satu faktor terjadinya ketimpangan sosial dalam dunia pendidikan, lebih mengejutkan lagi tatkala kita mengingat bahwa sarana memiliki hubungan dengan motivasi guru artinya sarana juga mempengaruhi kualitas seorang guru. Kedua faktor ini merupakan fokus yang seharusnya dibenahi dalam sistem zonasi namun pada kenyataannya dua faktor ini justru masih tetap terabaikan. Dari aspek hak sekolah dapat ditarik kesimpulan bahwasannya kebijakan zonasi perlu untuk dibenahi, sebab kebijakan ini justru menimbulkan masalah baru bagi sekolah. Meskipun tujuan kebijakan zonasi dinilai baik, adanya evaluasi dan pembenahan dirasa perlu demi mengatasi permasalahan yang timbul setelah berlangsung nya kebijakan tersebut.

Tidak ada lagi Hak Berkompetisi:Kebijakan zonasi ini menjadikan peserta didik kehilangan semangat untuk bersaing, karena lembaga pendidikan yang menerapkan kebijakan tersebut akan lebih mementingkan jarak dari pada prestasi. Siswa yang merasa lebih mampu untuk masuk dilembaga tersebut akan memilih mundur saat mengetahui lembaga tersebut menerapkan kebijakan zonasi, karena menurutnya tidak adil jika lembaga tersebut hanya mementingkan jarak daripada nilai. Motivasi belajar siswa menurun karena sistem zonasi ini yang menimbulkan pikiran yang salah dari peserta didik, Dengan tanggapan nya untuk apa saya belajar dengan giat kalau bersekolah saja harus di ukur dengan jarak. Maka akibatnya peserta didik tersebut ingin pindah tempat tinggal ke tempat tujuan sekolah yang siswa tersebut inginkan. Pemikiran yang terlalu di remehkan tentang keinginan peserta didik untuk pindah rumah yang lebih dekat ke sekolah impian guna masuk kedalam kawasan zonasi sekolah tersebut menimbulkan permasalahan baru yang tak di ramal sebelumnya yaitu adanya manipulasi Kartu Keluarga (KK) dan adanya kecurangan dalam Surat Keterangan Tidak Mampu (SKTM) dan jalur pindah domisili bagi orang tua yang dipindahkan kerja. Hal ini tentu tidak adil bagi mereka yang memiliki SKTM asli namun kalah telak dengan para pelaku yang menggunakan SKTM palsu (D. Wahyuni, 2019). Masih adanya tindak tanduk kecurangan dalam sistem zonasi ini dikhawatirkan akan menghilangkan kepercayaan masyarakat akan kesanggupan pemerintah untuk menanggulangi kegagapan dalam dunia pendidikan.

Kompetisi yang ada sebetulnya tidak benar-benar hilang karena kompetisi dalam sistem zonasi lebih dominan kepada kompetisi jarak bukan lagi kompetisi prestasi. Meski begitu agaknya pemerintah sudah mulai mendengarkan suara para peserta didik yang ingin prestasinya dilirik sekolah impian. Seperti yang dipaparkan sebelumnya bahwa ditahun 
2020, Kemdikbud telah meningkatkan kuota prestasi dari yang awalnya 15\% persen menjadi 30\% hal ini tentu membuka peluang lebih besar bagi anak-anak untuk dapat memilih sekolah impiannya tanpa pusing memikirkan jarak yang terlampau jauh. Meskipun kuota yang diberikan tidak setara dengan porsi kuota zonasi, tetapi hal ini cukup membantu para orang tua yang menginginkan anaknya dapat meraih sekolah yang di idamkan. Adapun yang melandasi Nadiem Makarim untuk tetap mempergunakan kebijakan zonasi, diantaranya sistem zonasi di terapkan karena sistem ini tidak hanya mengatur kuantitas dan kualitas sekolah tetapi juga meringankan peran guru dan meningkatkan kualitas guru dan peserta didik di seluruh daerah. Nadiem mengatakan bahwa pemerataan dengan zonasi saja tidak cukup. Ada dampak yang lebih besar yaitu pemerataan kuantitas dan kualitas guru yang memiliki banyak manfaat terhadap pemerataan pendidikan (Harususilo, 2019).

Permasalahan di tambah ketika para masyarakat yang pro dengan kebijakan zonasi cenderung membuat jalur lainnya justru sepi peminat sedang jalur zonasi membludak. Terbukti pada PPDB online yang dilakukan di Magelang mendapati keluhan masyarakat karena sistem zonasi yang terlalu luas membuat tidak semua sekolah mendapat siswa yang mendaftar di jalur prestasi. Bahkan dalam pelaksanaan PPDB online itu menyebutkan beberapa siswa berprestasi di Muntilan justru tidak tertarik dengan jalur prestasi dan memilih mendaftar di jalur lainnya. Hal yang sama juga terjadi di jalur perpindahan, karena tidak banyak orang tua yang mendapat perpindahan kerja di Magelang membuat jalur ini juga ikut sepi peminat (Wardhana \& Supriyoko, 2019).

Prestasi Kalah dengan Jarak:kebijakan zonasi ini juga dapat mempersempit kesempatan siswa yang berprestasi. Karena siswa yang berprestasi terkendala dengan sistem zonasi yang kita ketahui kuota untuk siswa berprestasi lebih kecil dibandingkan dengan kouta zonasi. Hal ini membuat siswa yang berprestasi hanya memiliki sedikit peluang untuk masuk ke sekolah favorit karena terkendala jarak dan kuota. Dengan demikian para peserta didik pun mengalah dengan masuk ke sekolah terdekat karena hanya memiliki kemungkinan kecil jika memaksa ke sekolah impian yang jaraknya tentu lebih jauh (Hendrawansyah \& Zamroni, 2020). Pandangan mengenai statement prestasi kalah dengan jarak pada pemikiran peserta didik tentu akan berpengaruh dalam motivasi belajarnya. Lingkungan yang beragam sebagai dampak implementasi zonasi ini pun sedikit banyak akan berpengaruh ke dalam diri peserta didik. Pengaruh yang didapat bisa saja menurunnya tingkat prestasi bahkan tidak adanya peningkatan ataupun penurunan. Mengingat lingkungan merupakan faktor utama yang mempengaruhi presetasi peserta didik. Pada sistem zonasi, ada dua faktor yang mempengaruhi prestasi peserta didik sebagai hasil akhir dari produk pendidikan yaitu karakteristik atau latar belakang keluarga siswa dan lingkungan sekolah atau teman sebaya (Syakarofath, Sulaiman, \& Irsyad, 2020).Dalam sebuah penelitian menemukan bahwasannya sistem zonasi ini bukan hanya berdampak pada karakteristik peserta didik yang diterima tapi juga berdampak dalam proses pembelajaran di kelas. Pada dasarnya para siswa baru yang diterima melalui jalur zonasi mendapati jarak rumah yang jauh lebih dekat dengan sekolah dibanding siswa yang diterima melalui jalur prestasi. Namun, komposisi nilai rendah dan siswa yang lebih beragam banyak di dominasi oleh peserta didik yang diterima lewat jalur zonasi dibanding peserta yang diterima lewat jalur prestasi. Situasi ini membuat guru mau tidak mau harus beradaptasi dengan cepat. Para guru cenderung mengajar siswa yang memiliki kemampuan rata-rata tinggi namun dengan adanya kebijakan zonasi guru harus menghadapi siswa yang memiliki kemampuan rendah dan beragam. Padahal, ketrampilan mengajar seorang guru yang mendapat siswa dengan kemampuan tinggi berbeda dengan ketrampilan guru yang 
mendapat siswa dengan kemampuan rendah. Hal ini tentu membuat seorang guru harus menguasai dua ketrampilan secara langsung (Rihardi \& Yusliwidaka, 2020). Perubahan dilingkungan sekolah akibat pemberlakuan sistem zonasi juga dirasakan oleh SMAN 1 Surakarta. Bukan hanya perubahan dalam proses pembelajaran tapi juga perubahan budaya di lingkungan sekolah tersebut. Perubahan budaya yang dialami di SMAN 1 Surakarta membuat wakil kepala sekolah bidang kurikulum menyimpulkan bahwa antara prestasi dan karakter memiliki keterkaitan. Melihat para peserta kelas X yang diterima dijalur zonasi memiliki kebiasaan yang sama untuk bolos sekolah seperti kakak tingkatnya di kelas XII. Budaya baru ini tentu membuat para guru harus memahami karakter siswa yang beragam demi Kegiatan Belajar Mengajar (KBM) yang maksimal. Dalam pengamatan tersebut kembali mengemukakan bahwa peserta kelas $\mathrm{X}$ yang diterima dijalur zonasi memiliki motivasi belajar yang rendah dibanding kelas diatasnya. Banyaknya nilai yang turun dan mata pelajaran yang tidak tuntas bahkan beberapa memilih mengundurkan diri karena tidak terbiasa dengan pola pembelajaran (Y. S. D. Wahyuni, Nurhadi, \& Nurcahyono, 2020). Dari hasil dua pengamatan tersebut, dapat disimpulkan bahwa penerapan zonasi juga harus dibarengi dengan persiapan akan adanya perubahan di lingkungan sekolah. Perlunya mempersiapkan kualitas guru dan sosialisasi terkait budaya sekolah di rasa perlu dilakukan untuk meminimalisir adanya kesenjangan baru atau label baru yang diberikan kepada anakanak jalur zonasi.

\section{Simpulan dan Saran}

Simpulan dalam penelitian ini adalah kebijakan zonasi yang diterapkan pemerintah sebetulnya telah berhasil menghapuskan label sekolah favorit dan non favorit di ranah pendidikan. Namun, pemerintah belum berhasil untuk mengubah streotipe dan stigma terkhusus para orang tua tentang sekolah favorit dan non favorit. Ketimpangan yang terjadi bukan karena sekolah tersebut di labeli favorit maupun non favorit tetapi ketimpangan terjadi karena adanya ketidakmerataan kualiatas pendidikan di dalam sebuah sekolah. Maka dari itu penghapusan label favorit non favorit tidak begitu berpengaruh jika tidak ada tindakan lebih lanjut untuk meningkatkan kualitas setiap sekolah. Mulai dari kualitas guru, sarana prasarana sampai pada input siswa. Kebijakan zonasi yang dibuat pemerintah hanya berhasil membenahi permasalahan pada input siswa sehingga zonasi diterapkan untuk meningkatkan input siswa di suatu sekolah. Sedangkan kualitas guru dan prasarana masih menjadi fokus yang terabaikan.

Pengabaian pada aspek kualitas guru dan prasarana dalam sistem zonasi justru membuat ranah pendidikan memiliki permasalahan yang baru. Dimana kebijakan yang jalan tidak dibarengi adanya sarana dan prasarana membuat peserta didik banyak yang tidak menoleh ke sekolah terdekat dan memilih sekolah yang jauh karena merasa lebih lengkap fasilitasnya. Tidak hanya itu, membludaknya peserta didik disuatu sekolah juga disebabkan tidak meratanya persebaran penduduk. Sehingga sekolah yang berada di pemukiman padat penduduk menerima peminat jalur zonasi melampaui kuota begitu juga sebaliknya pada sekolah yang berada di pemukiman minim penduduk. Kebijakan zonasi disisi lain menimbulkan permasalahan baru yaitu pelabelan anak zonasi dan non zonasi dimana anak zonasi selalu dikatakan sebagai anak yang memliki kemampuan rendah sehingga memunculkan ketimpangan sosial baru dalam pendidikan. Perubahan budaya dalam lingkungan sekolah juga menjadi dampak dari pemberlakuan zonasi. Guru dituntut untuk mengubah mindsetnya dalam mengartikan karakter yang beragam pada peserta didik. Hal ini membuat guru diharuskan memiliki dua ketrampilan sekaligus dalam mengajar peserta didik yang heterogen akibat pemberlakuan zonasi. 
Berdasarkan simpulan di atas maka saran yang diajukan dalam penelitian ini adalah:(1). Pemerintah harus memperhatikan kualitas sekolah di daerah yang padat penduduk. Hal ini agar sekolah yang ada memiliki fasilitas yang memadai sesuai dengan jumlah peserta didik, (2). Pemerintah bisa menambah pelatihan untuk para guru mengingat karakter siswa yang dihadapi akan semakin beragam sebagai konsekuensi dari kebijakan zonasi dan (3). Guru hendaknya memberi pengarahan di awal mengenai kebudayaan di lingkungan sekolah agar peserta didik dapat menyesuaikan dirinya serta guru harus memperhatikan tidak adanya kesenjangan baru antara siswa jalur zonasi dan jalur lainnya yang akan memicu pembullyan.

\section{Daftar Rujukan}

Abbas, H. (2019). Meluruskan Arah Pendidikan Isu-Isu Kritis Pendidikan Solusi dan Prospek. Jakarta: Kompas.

Aminah, Siti (2018). Implementasi Permendikbud No 17 Tahun 2017 Tentang Penerimaan Peserta Didik Baru di SMA Negeri 1 Prambon Nganjuk Tahun 2017/2018. Undergraduate (S1) thesis, IAIN Kediri. Diakses dari http://etheses.iainkediri.ac.id/id/eprint/766

Arwildayanto, Arifin, S., \& Sumar, W. T. (2018). Analisis Kebijakan Pendidikan Kajian Teoritis, Eksploratif Dan Aplikatif. Bandung: Cendekia Press

Harususilo, Y. E. (2019). 3 Alasan Mendikbud Nadiem Pertahankan Sistem Zonasi di PPDB 2020. Retrieved April 25, 2021, from edukasi.kompas.com website: https://edukasi.kompas.com/read/2019/12/17/07362461/3-alasan-mendikbudnadiem-pertahankan-sistem-zonasi-di-ppdb-2020?page=all\#page 2

Hendrawansyah, H., \& Zamroni, Z. (2020). Evaluasi Kebijakan Sistem Zonasi Dalam Penerimaan Siswa Baru Sekolah Menengah Atas. Jurnal Kependidikan: Penelitian Inovasi Pembelajaran, 4(1), 70-82. https://doi.org/10.21831/jk.v4i1.27007

Yuliani, M. (2019). Ketimpangan Pendidikan di Era Globalisasi. https://doi.org/10.31227/osf.io/xnw4e

Yusnilaningsih, R. (2019). Total Pendaftar PPDB SMP Kota Bekasi Melebihi Kapasitas, tapi Beberapa Jalur Kurang Peminat. Retrieved April 25, 2021, from www.pikiranrakyat.com website: https://www.pikiran-rakyat.com/pendidikan/pr-01314570/totalpendaftar-ppdb-smp-kota-bekasi-melebihi-kapasitas-tapi-beberapa-jalur-kurangpeminat

Jamil, F. (2020). Korelasi Sarana Prasarana Pendidikan Dengan Motivasi Mengajar Guru. https://doi.org/10.35542/osf.io/a5v9j

Kemendikbud, T. K. P. K. dan B. K. dan L. M. (2018). Semua Bisa Sekolah! Zonasi untuk Pemerataan yang Berkualitas. Retrieved April 25, 2021, from kominfo.go.id website: https:/www.kominfo.go.id/content/detail/13689/semua-bisa-sekolah-zonasi-untukpemerataan-yang-berkualitas/0/artikel_gpr\#: :text=Sistem zonasi merupakan salah satu,serta pemerataan kualitas pendidikan nasional.\&text=Zonasi dipandang strategis untuk memper

Mahpudin, M. (2020). Hak Warganegara Yang Terampas: Polemik Kebijakan Sistem Zonasi dalam Pendidikan Indonesia. Jurnal Transformative, 6(2), 148-175. https://doi.org/10.21776/ub.transformative.2020.006.02.2 
Pengelola web kemdikbud. (2019). Penetapan Zonasi Sekolah dalam Proses Perampungan. Retrieved April 25, 2021, from kemdikbud.go.id website: https://www.kemdikbud.go.id/main/blog/2019/02/penetapan-zonasi-sekolah-dalamproses-perampungan

Pengelola web kemdikbud. (2019). PPDB 2020 Tetap Sistem Zonasi, Kuota Jalur Prestasi Ditambah. Retrieved April 25, 2021, from kemdikbud.go.id website: https://www.kemdikbud.go.id/main/blog/2019/12/ppdb-2020-tetap-sistem-zonasikuota-jalur-prestasi-ditambah

Perdana, N. S. (2019). Implementasi Ppdb Zonasi Dalam Upaya Pemerataan Akses Dan Mutu Pendidikan. Jurnal Pendidikan Glasser, 3(1), 78. https://doi.org/10.32529/glasser.v3i1.186

Pradewi, G. I., \& Rukiyati, R. (2019). Kebijakan Sistem Zonasi Dalam Perspektif Pendidikan. Jurnal Manajemen Dan Supervisi Pendidikan, 4(1), 28-34. https://doi.org/10.17977/um025v4i12019p028

Rihardi, S. A., \& Yusliwidaka, A. (2020). Menakar Sistem Zonasi Penerimaan Siswa Baru Di Era Desentralisasi Pendidikan. VOX EDUKASI: Jurnal Ilmiah Ilmu Pendidikan, 11(1), 1-13. https://doi.org/10.31932/ve.v11i1.540

Syakarofath, N. A., Sulaiman, A., \& Irsyad, M. F. (2020). Kajian Pro Kontra Penerapan Sistem Zonasi Pendidikan Di Indonesia. Jurnal Pendidikan Dan Kebudayaan, 5(2), 115-130. https://doi.org/10.24832/jpnk.v5i2.1736

Suwarto, S. (2009). Pengembangan tes dan analisis hasil tes yang terintegrasi dalam program komputer. Jurnal Penelitian dan Evaluasi Pendidikan, 13(1), 40-56.

Suwarto, S. (2017). Pengembangan tes ilmu pengetahuan alam terkomputerisasi. Jurnal Penelitian dan Evaluasi Pendidikan, 21(2), 153-161.

Thoha, M., \& Ghazali, H. A. (2020). Dampak Penerapan Sistem Zonasi dalam Penerimaan Peserta Didik Baru. TADRIS: Jurnal Pendidikan Islam, 15(1), 141. https://doi.org/10.19105/tjpi.v15i1.3302

Wahyuni, D. (2019). Pro Kontra Sistem Zonasi Penerimaan Peserta Didik Tahun Ajaran 2018/2017. Info Singkat Bidang Kesejahteraan Sosial Puslit Badan Keahlian DPR, $X(14), 13-18$.

Wahyuni, Y. S. D., Nurhadi, N., \& Nurcahyono, O. H. (2020). Strategi manajemen sekolah dalam menghadapi pemberlakuan sistem zonasi. Jurnal Akuntabilitas Manajemen Pendidikan, 8(2), 124-136. https://doi.org/10.21831/jamp.v8i2.31858

Wardhana, L. P., \& Supriyoko, S. (2019). Manajemen Penerimaan Peserta Didik Baru Secara Online Berbasis Zonasi, Prestasi dan Perpindahan. Media Manajemen Pendidikan, 2(2), 228. https://doi.org/10.30738/mmp.v2i2.5063 